\title{
KONTRIBUSI PENGELOLAAN SARANA DAN PRASARANA DALAM MENINGKATKAN KUALITAS SARANA DAN PRASARANA PENDIDIKAN
}

\author{
Oleh: Andra Novrianto.S \\ Universitas Negeri Padang \\ andra.saaputra@gmail.com
}

\begin{abstract}
Abstrak
Artikel ini membahas tentang bagaimana sebenarnya cara meningkatkan usia pakai dan kualitas barang yang ada. Barang tersebut lebih spesifik kepada sarana dan prasarana yang ada. Karena dapat dilihat, bahwasannya sarana yang lengkap dapat bertahan pada umur yang relatif sebentar, seperti keadaan kursi baru, yang hanya bertahan bagus dalam jangka relatif lebih singkat dari yang seharusnya. Terkadang kursi tersebut sudah mengalami patah lengan, vobek bagian gabus dan lain-lain, dan masih banyak lagi sarana dan prasarana yang mengalami nasib yag sama.sehingga melihat hal tersebut perlu adanya dilakukan pemiliharaan dengan cara memberikan pesan-pesan terkait pemeliharaan yang ada pada masing-masing sarana yang ada. Dengan demikian akan menjadikan orang yang melihat sarana tersebut lama kelamaan akan menjadi terpengaruh dan menjadi sebuah kebiasaan.
\end{abstract}

Kata Kunci: pengelolaan, sarana dan prasarana, manfaat, sarana dan pasaran pendidikan.

\section{PENDAHULUAN}

Keberhasilan dalam pellaksanaan pendidikan pada sebuah lembaga pendidikan atau lebih luas lagi pada sebuah sekolah ditentukan oleh banyak faktor yang menjadi pendukun terlasannya pendidikan yang baik. Dalam (Peraturan Pemerintah Repoblik Indonesia Nomor 23 2013) dijelaskan ada setidaknya delapan standar nasional pendidikan yang harus dipenuhi oleh satuan pedidikan dalam mencapai sekolah yang bermutu. Pada pasal 1 ayat 9 dalam (Peraturan Pemerintah Repoblik Indonesia Nomor 23, 2013) dijelaskan adanya standar yang harus dipenuhi sekolah, yaitu standar saran dan parasarana.

Standar sarana dan prasarana yang harus dipenuhi oleh setiap sekolah itu adalah segala sesuatu yang berhubungan dengan keberlangsungan proses belajar mengajar dalam sebuah sekolah. Sebagai mana standar sarana dan prasarana yang dimaksudkan dalam (Peraturan Pemerintah Repoblik Indonesia Nomor 23, 2013) adalah "kriteria mengenai ruang belajar, tempat berolahraga, tempat beribadah, perpustakaan, laboratorium, bengkel kerja, tempat bermain, tempat berkreasi dan berekreasi serta sumber belajar lain, yang diperlukan untuk menunjang proses pembelajaran, termasuk penggunaan teknologi informasi dan komunikasi”

Dalam rangka menyelengarakan pendidikan di Indonesia dikenal dengan adanya jenis pendidikan formal, non formal dan informal. Pada pasal 1 ayat 11-13 dalam (undang undang repoblik indonesia nomor 20, 2003) dijelaskan mengenai pendidikan formal, non formal dan pendidikan informal secara jelas. Ketiga jenis pendidikan tersebut mempunyai kebutuhan yang pada umumnya sama dalam hal penggunaan sarana dan prasarana pendidikan. Mengapa demikian? Karena sebagai mana dalam (Peraturan Pemerintah Repoblik Indonesia Nomor 23, 2013), telah di jelaskan bahwa sarana dan prasrana pendidikan itu mencakup sseluruh kebutuhan barang yang mendukung pendidikan secara langsung maupun tidak langsung, seperti saran ibadah gedung belajar, media pembelajaran dan lainlain.

Pentingkah melakukan penegelolaan sarana dan prasarana pada sekolah? Menurut (Sudjana, 2004) pengelolaan tersebut perlu dilakukan dalam rangka melayani peserta didik dengan sangat baik, sehingga tujuan dari diselenggarakannya pendidikan dapat terwujud dengan baik. Artinya apa? Pengelolaan 
yang di utarakan oleh (Sudjana, 2004) merujuk pada pegeloalaan pendidikan non formal. Artinya apa? Seluruh sekolah memerlukan pengelolaan dengan baik. Selain pendapat Sudjana, dalam (Peraturan Pemerintah Repoblik Indonesia Nomor 23, 2013) dijelaskan bahwasannya standar nasional Pendidikan adalah kriteria minimal tentang sistem pendidikan di seluruh wilayah hukum Negara Kesatuan Republik Indonesia. Artinya apa? Dalam standar nasional pendidikan terdapat standar sarana dan prasarana yang perlu untuk dikelola dengan sangat baik. Dari penjekasan diatas, permaslahan dalam artikel ini adalah kontribusi sarana dan prasarasarana dalam mendukng pembelajaran pada sekolah.

\section{KAJIAN TEORETIS Sarana dan Prasarana}

Sarana dan prasarana merupakan suatu hal yang berbeda satu sama lainnya. Perbedaan tersebut mencakup pada hal cakupan antara sarana dan prasarana. Walaupun terdapat perbedaan antara kedunnya tersebut, antara sarana dan prasarana tidak akan pernah dapat terpisahkan dalam pelaksanaan dan pngelolaan sarana dan prasarana tersebut.

Sarana merupakan segala alat yang digunakan dalam suatu proses yang mana alat tersebut berperan secara langsung dalam keberllangsungan proses belajar mengajar di dalam kelas dan poroses pendidikan secara umum. Sedangkan prasaran adalah alat yang digunakan dalam proses yang mana penggunaanya dapat mendukung kegiatan tersebut secara tidak langsung. Dalam (Pahlevi, Imron, \& Kusumaningrum, 2016) Sarana berarti segala sesuatu yang dipakai untuk mengerjakan sesuatu dalam mencapai tujuan. Sedangkan kaitannya dengan pendidikan, sarana adalah peralatan, bahan dan perlengkapan yang secara langsung dipergunakan dan menunjang proses pembelajaran. Dalam konteks proses belajar mengajar, sarana dapat berupa gedung, ruang kelas, meja, kursi, serta alat-alat dan media pengajaran. Prasarana adalah segala sesuatu yang merupakan penunjang utama terselenggaranya suatu proses. Sementara yang dimaksud prasarana pendidikan adalah fasilitas yang secara tidak langsung menunjang jalannya proses pendidikan, seperti asrama, halaman, kebun, taman sekolah, jalan menuju sekolah.

Untuk lebih memudahkan membedakan konsep sarana dan prasarana ini, dapat diambil analogi bepergian dari padang ke bukit tinggi. Sarana yang digunakan untuk menuju bukit tinggi adalah mobil, motor, bus dan kendaraan umum lainnya. Selain itu ada sarana penunjang kenyamanan dan pendukung untuk sampai ke bukit tinggi, seperti rumah makan, toilet umum SPBU dan lain-lain.

Artinya perbedaan sarana dan prasara dapat dilihat dari segi sifat penggunaan sarana dan prasarana itu sendiri. Sarana bersifat mendukung kegiatan secara langsung untuk mencapai tujuan seperti mobil, motor, bus dan kendaraan umum lainnya sedangkan prasarana mendukung kegiatan secara tidak langsung seprti tilet umum, rumah makan dan SPBU

\section{Manajemen sarana dan prasarana}

Manajem merupakan suatu seni untuk menglola sesuatu agar dapat mencapai tujuan proses secara lebih efektif dan efisien. Selain itu kata manajemen sering diartikan secara kata dengan kata mengelola, menata, mengarahkan dan lain-lain. Selain itu kata manejemen lebih sering digambarkan dengan singkatan POAC planing (perencanaan), organiting (pengorganisasian), actuating (pelaksanaan), controling (pengawasan). Hal ini diungkapkan oleh Terry dalam (Karyoto, 2016) sebagai berikut: (1) Planning adalah kegiatan yang menentukan berbagai tujuan dan penyebab tindakan-tindakan selanjutnya. (2) Organizing adalah kegiatan membagi pekerjaan di antara anggota kelompok dan membuat ketentuan dalam hubungan-hubungan yang diperlukan. (3) Actuating adalah kegiatan menggerakkan anggotaanggota kelompok untuk melaksanakan pekerjaan sesuai dengan tugas masing-masing. (4) Controlling adalah kegiatan untuk menyesuaikan antara pelaksanaan dan rencana-rencana yang telah ditentukan

Walaupun pengelolaan secara umum hanya ada sekitar empat tersebut, namun pada pelaksanaannya lebih dari pada itu kegiatan manajemen tersebut seperti adanya istilah suppervisi, budgeting, evaluating, dan masih banyak lagi. Ke empat fungsi manajemen tersebut merupakan pengklasifikasian fungsi manajemen secara menyeluruh.

Sementara tujuan dilakukannya manajemen saran dan prasarana dikarenakan adanya keterbatasan dari sumber daya yang ada pada suatu organisasi. Sehingga menuntut adanya tujuan secara bersama dalam menyukseskan tujuan organisasi. Manajemen sarana dan prasarana pendidikan merupakan usaha untuk mendayagunakan seluruh sarana untuk tujuan organisasi secara efektif dan efisien. Hal tersebut 
dikemukakan oleh (Bafadal 2008) Manajemen sarana dan prasarana pendidikan dapat didefinisikan sebagai proses kerja sama pendayagunaan semua sarana dan prasarana pendidikan secara efektif dan efisien.

\section{PEMBAHASAN}

\section{Kontribusi Sarana Prasarana pada Sekolah.}

Menunjang Kualitas Siswa.

Tidak dapat dipungkiri bahwa dalam proses pendidikan, bahwa kualitas pendidikan tersebut juga di dukung dengan sarana dan prasarana yang menjadi standar sekolah atau instansi pendidikan yang terkait. Sarana dan prasarana sangat mempengaruhi kemampuan siswa dalam belajar. Hal ini menunjukkan bahwa peranan sarana dan prasarana sangat penting dalam menunjang kualitas belajar siswa. Misalnya saja sekolah yang berada di kota yang sudah memiliki faslitas laboratorium komputer, maka anak didiknya secara langsung dapat belajar komputer sedangkan sekolah yang berada di desa tidak memiliki fasilitas itu dan tidak tahu bagaimana cara menggunakan komputer kecuali mereka mengambil kursus di luar sekolah.

Pengelolaan itu dimaksudkan agar dalam menggunakan sarana dan prasarana di sekolah bisa berjalan dengan efektif dan efisien. Pengelolaan sarana dan prasarana merupakan kegiatan yang amat penting di sekolah, karena keberadaannya akan sangat mendukung terhadap suksesnya proses pembelajaran di sekolah. Dalam mengelola sarana dan prasarana di sekolah dibutuhkan suatu proses sebagaimana terdapat dalam manajemen yang ada pada umumnya, yaitu mulai dari perencanaan, pengorganisasian, penggerakan, pemeliharaan dan pengawasan. Apa yang dibutuhkan oleh sekolah perlu direncanakan dengan cermat berkaitan dengan sarana dan prasarana yang mendukung semua proses pembelajaran.

\section{Membantu Proses Pembelajaran}

Sekolah merupakan lembaga sosial yang keberadaannya merupakan bagian dari sistem sosial bangsa yang bertujuan untuk mencetak manusia susila yang cakap, demokratis, bertanggung jawab, beriman, bertaqwa, sehat jasmani maupun rohani, memiliki pengetahuan dan keterampilan, berkepribadian yang mantap serta mandiri. Agar tujuan tersebut dapat tercapai maka dibutuhkan kurikulum yang kuat, baik secara infrastruktur maupun suprastruktur. Kurikulum ini nantinya yang akan digunakan sebagai pedoman dalam melaksanakan seluruh kegiatan pembelajaran, khususnya interaksi antar pendidik dengan peserta didik dalam kegiatan belajar mengajar. Guru sebagai pendidik dituntut untuk dapat menyelenggarakan pembelajaran yang menarik dan bermakna sehingga prestasi yang dicapai dapat sesuai dengan target yang telah ditetapkan.

Setiap mata pelajaran memiliki karakter yang berbeda dengan pelajaran lainnya. Dengan demikian, masing-masing mata pelajaran juga memerlukan saranapembelajaran yang berbeda pula. Dalam menyelenggarakan pembelajaran guru pastinya memerlukan sarana yang dapat mendukung kinerjanya sehingga pembelajaran dapat berlangsung dengan menarik. Dengan dukungan sarana pembelajaran yang memadai, guru tidak hanya menyampaikan materi secara lisan, tetapi juga dengan tulis dan peragaan sesuai dengan sarana prasaranayang telah disiapkan guru.

Guru membutuhkan sarana pembelajaran dalam menunjang kegiatan pembelajaran. Selain kemampuan guru dalam menyelenggarakan kegiatan pembelajaran, dukungan dari sarana pembelajaran sangat penting dalam membantu guru. Semakin lengkap dan memadai sarana pembelajaran yang dimiliki sebuah sekolah akan memudahkan guru dalam melaksanakan tugasnya sebagai tenaga pendidikan. Begitu pula dengan suasana selama kegiatan pembelajaran. Sarana pembelajaran harus dikembangkan agar dapat menunjang proses belajar mengajar. Yamin menyebutkan beberapa hal yang perlu dikembangkan dalam menunjang proses belajar mengajar: 1) perpustakaan, 2) sarana penunjang kegiatan kurikulum, dan 3) prasarana dan sarana kegiatan ekstrakurikuler dan mulok.

Mengingat pentingnya sarana prasarana dalam kegiatan pembelajaran, maka peserta didik, guru dan sekolah akan terkait secara langsung. Peserta didik akan lebih terbantu dengan dukungan sarana prasarana pembelajaran. Tidak semua peserta didik mempunyai tingkat kecerdasan yang bagus sehingga penggunaan sarana prasarana pembelajaran akan membantu peserta didik, khususnya yang memiliki kelemahan dalam mengikuti kegiatan pembelajaran. Bagi guru akan terbantu dengan dukungan fasilitas sarana prasarana. Kegiatan pembelajaran juga akan lebih variatif, menarik dan bermakna. Sedangkan sekolah berkewajiban sebagai pihak yang paling bertanggung jawab terhadap pengelolaan seluruh kegiatan yang diselenggarakan. Selain menyediakan, 
sekolah juga menjaga dan memelihara sarana prasarana yang telah dimiliki.

\section{Menunjang Hasil Belajar}

Dalam penelitian yang dilakukan oleh (Fadhilah, 2014) mengatakan bahwa Sarana Yang Menunjang Proses Pembelajaran di SD Islam Al Syukro Universal meliputi Peralatan pendidikan, seperti papan tulis, bangku, meja, dan lain-lain yang terdapat di dalam kelas dan sekitar sekolah, media pendidikan yang digunakan untuk membantu komunikasi dalam pembelajaran, buku sebagai sumber belajar, meliputi: Buku teks pelajaran menjadi pegangan peserta didik dan guru untuk setiap mata pelajaran, dan Buku pengayaan untuk memperkaya pengetahuan peserta didik dan guru. Buku referensi adalah buku rujukan untuk mencari informasi atau data tertentu, dan

Sumber belajar lainnya adalah sumber informasi dalam bentuk selain buku meliputi jurnal, majalah, surat kabar, poster, situs (website), dan compact disk.

Hasil wawancara menyatakan bahwa tanpa sarana dan prasarana tidak akan berjalan dengan baik proses KBM. Sarana dan prasarana sebagai pendukung proses belajar siswa, tentunya harus memadai. Salah satunya perpustakaan sangat dimanfaatkan karena sebagai salah satu sumber pembelajaran siswa. Siswa dapat mengakses perpustakaan sebagai bahan pembelajaran, dengan memperoleh bahan pelajaran dari buku-buku yang ada di perpustakaan. Dengan

peminjaman buku yang dilakukan oleh siswa atau anggota lainnya, siswa dapat menggunakan buku tersebut. Dalam suatu proses belajar mengajar di SD Islam Al Syukro Universal, sarana dan prasarana merupakan salah satu penunjang suatu proses belajar mengajar. Seorang siswa dalam melakukan aktivitas belajar memerlukan adanya dorongan tertentu agar kegiatan

\section{SOLUSI DARI PERMASLAHAN SARANA DAN PRASARANA}

Dalam mengatasi masalah sarana dan prasarana yang ada, seperti kurangnya kesaadaran para pengguna sarana dan prasarana. Sehingga ketika kesadaran pengguna tersebut telah ada dan tertanam dlam diri mereka, maka akan dapat menjadikan perawatan srana dan prasarana menjadi lebih mudah dan efisien.

Pengelolaan sarana dan prasarana dengan cara demikian, akan mampu membuat para pengguna sarana mampu menjadikan diri mereka terbiasa menjadi sebuah tabiat mereka. Karena sesuatu yang berlangsung berulang dan terus menerus akan menjadikan sebuah kebiasaan dan bahkan akan menjadikan sebuah tabiat.

Dari hal tersebutlah penulis mengambil pemutusan masalah agar sarana dan prasarana sekolah terkelola dengan baik. Dengan cara memberikan nama-nama dan pesan pesan terkait dengan pengelolaan sarana dan prasaran. Misalnya kata-kata "jangan duduk di tangan-tangan kursi" "tempat sampah bukan yntuk ditendang" dan masih banyak lagi kata-kata lain.

Dengan adanya kata-kata tersebut, misalnya jangan duduk di tangan-tangan kursi, maka ketika seorang yang telah melihat dan selalu membaca tulisan tersebut, maka akan menjadi pola pikir yang tertanam dalam kepala mereka bahwasannya duduk di tangan kursi memang tidak baik dan tidak diperbolehkan. Hal terebut akan juga dialami oleh setiap orang yang melihat dan membaca tulisan tersebut.

\section{SIMPULAN DAN SARAN \\ Simpulan}

Sarana merupakan sesuatu alat yang dapat diigunakan untuk menunjang tercapainya tujuan suatu kegiatan secara efektif. Sarana pendidikan adalah alat yang digunakan untuk menujang kegiatan pendidikan secara langsung, dan memberikan dampak yang sangat besar untuk keperluan pencapaian tujuan pendidikan pada lingkungan sekolah, contoh dari sarana pendidikan adalah gedung sekolah papan tulis sekolah, meja dan kursi sekolah, ruang kelas dan sarana lainnya.

Prsarana merupakan alat yang digunakan untuk menunjang ketercapaian tujuan peendidikan. Prasarana pendidikan diantaranya adalah media pembelajaran, kafe taria sekolah, alat transportasi sekolah, gedung UKS, keamaann di sekolah dan sarana penunjang lainnya

Manfaat yang dapat dari kontribusi sarana dan prasrana pendidikan di sekolah adalah dapat menunjang kualitas siswa, menunjang proses belajar siswa dan menunjang hasil belajar sisiwa.

\section{Saran}

Manfaat yang ada pada artikel ini sebenarnya masih dalam garis-garis besar yang belum terspesifikasi secara detail, karena penulis masih mengkaji satu karya tulis ilmiah, yaitu skripsi yang berjudul Peranan sarana dan prasarana pendidikan guna menunjang hasil belajar siswa di sd islam al syukro 
universal yang disusun oleh (Fadhilah, 2014). Sedangkan masih banyak yang membahas mengenai sarana dan prasarana pendidikan. Oleh karena itu penulis menyarankan pada penulis berikutnya untuk membahasnya secara detail.

\section{DAFTAR PUSTAKA}

Bafadal, I. (2004). Manajemen Perlengkapan Satuan pendidikan. Jakarta: Bumi Aksara.

Fadhilah, N. I. (2014). Peranan sarana dan prasarana pendidikan guna menunjang hasil belajar siswa di sd islam al syukro universal.

Karyoto. (2016). Dasar-Dasar Manajemen. jakarta: Graspindo.

Pahlevi, R., Imron, A., \& Kusumaningrum, D. E. (2016). Manajemen saranan dan prasarana untuk meningkatkan mutu penbelajaran. Manajemen Pendidikan, 25(1), 88-94.

Peraturan Pemerintah Repoblik Indonesia Nomor 23. perubahan atas PP No. 19 Thn. 2005 tentang standar nasional pendidikan (2013).

Sudjana, D. (2004). Pendidikan Nonformal: Wawasan, Sejarah Perkembangan, Filsafat \& Teori Pendukung, serta Asas. Bandung: Falah Production. Bandung: Falah Production.

undang undang repoblik indonesia nomor 20. (2003). sistem pendidikan nasional, 6-8. https://doi.org/10.16309/j.cnki.issn.10071776.2003.03.004 